\title{
Production and Immobilization of Halophilic Invertase Produced from Honey Isolate Aspergillus niger EM77 (KF774181)
}

\author{
Mona Abdeltawab Esawy ${ }^{1, *}$, Amany Lotfy Kansoh ${ }^{2}$, Zeinab Hassan Kheiralla ${ }^{3}$, \\ Hala Abd Elmonem Ahmed ${ }^{3}$, Tarek Aly-Kamal Kahil ${ }^{2}$ and Eman Karam Abd El-Hameed ${ }^{2}$
}

\author{
${ }^{1}$ Chemistry of Natural and Microbial product Dept., Pharmaceutical industry Dev, National Research Centre \\ Dokki, Cairo, Egypt \\ ${ }^{2}$ Microbial Chemistry Department, National Research Centre, Cairo, Egypt \\ ${ }^{3}$ Botany Department University College of Women for Arts, Science and Education Ain Shams University, \\ Cairo, Egypt
}

\begin{abstract}
Honey isolate Aspergillus niger EM77 was a good halophilic invertase producer in the presence of wheat bran as a complete medium $(114.55 \mathrm{U} / \mathrm{g}$ ), using solid state fermentation technique. Different parameters influence the enzyme productivity such as different $\mathrm{pH}$ values, temperature, incubation period, nitrogen and carbon sources were investigated. The optimum $\mathrm{pH}$, temperature and incubation period for enzyme production were $5.5,30^{\circ} \mathrm{C}$ and $72 \mathrm{hrs}$, respectively. Sucrose at $2 \%$ was more suitable carbon source for invertase production $(144.39 \mathrm{U} / \mathrm{g})$ and $\left(\mathrm{NH}_{4}\right)_{2} \mathrm{SO}_{4}$ at $0.15 \%$ was the ideal nitrogen source. Among different metals ions $\mathrm{MnSO}_{4}$ enhanced the enzyme productivity than other tested ions to $194.71 \mathrm{U} / \mathrm{g}$. The partially purified enzyme was successfully entrapped in polyvinyl alcohol sponge shielded with agar starch layer (PVAsp Gs) and achieved $71 \%$ immobilization yield. The optimum conditions for immobilization were: $\mathrm{pH} 5.2$, an incubation time of $15 \mathrm{~min}$ and a protein concentration of $250 \mathrm{mg} / \mathrm{ml}$. Immobilized enzyme was reused 12 times with $29 \%$ activity loss. The free enzyme lost its activity completely at $70^{\circ} \mathrm{C}$ after 45 minute and the immobilized form retained $80 \%$ of its activity at the same condition. The free and immobilized form reported extreme halophilic property since the highest enzyme activity was obtained between $3.5-5 \mathrm{M}$.
\end{abstract}

Keywords: Honey isolate, invertase, Aspergillus awamori, immobilization, entrapment.

\section{INTRODUCTION}

Extreme environments are too harsh for normal life to exist, but a variety of bacteria and fungi could survive. These organisms have evolved to exist in these extreme environments and fall into a number of different categories, including halotolerant, moderately, borderline and extremely halophilic [1]. In the last few years, honey isolates take attention as new source for enzymes with unique feature [2, 3]. Since the halophilic enzymes possess salt-enriched solvation shells [4], they are constructed to retain catalytic activity in environments with low water activity, such as in the presence of high levels of organic solvents. Such properties could be of interest in a variety of applications [5].

Invertase is a commercially important enzyme known as a ( $\beta$-D-fructofuranoside fructohydrolase, $\beta$ fructofuranosidase, sucrase, invertin, saccharase; EC 3.2.1.26) catalyses the irreversible hydrolysis of nonreducing fructofuranosidic terminal. The hydrolysis of sucrose yields an equimolar mixture of glucose and fructose, known as invert syrup, is widely used in food

*Address correspondence to this author at the Chemistry of Natural and Microbial product Dept., Pharmaceutical industry Dev, National Research Centre Dokki, Cairo, Egypt; Tel: +20 2 33335479; Fax: +20 2 3370597; E-mail: mona_esawy@hotmail.com and beverage industries, residues of sucrose and related glycosides $[6,7]$. Hence, one of the important applications of invertase lies in the production of noncrystallizable sugar syrup from sucrose. Due to its hygroscopic nature, invert syrup is used as a humectant in the manufacture of soft candies and fondants. Invertase is also used whenever sucrose containing substrates are subjected to fermentation viz. production of alcoholic beverages, lactic acid, glycerol etc. Due to the associated inulinase activity, it is also used for the hydrolysis of inulin (polyfructose) to fructose. Other uses of the enzyme include, manufacture of artificial honey, plasticizing agents used in cosmetics, drug and paper industries and as enzyme electrodes for the detection of sucrose. Invertase is also able to catalyze the hydrolysis of raffinose and stachyose [8, 9]. In addition it may be used to obtain fructooligosaccharides (FOS) used as prebiotic substance [10].

The production of invertase by filamentous fungi under submerged (SbmF) or solid-sate fermentation (SSF) has been reported [11, 12]. SSF is characterized by development of microorganism in a low aqueous content on a non-soluble material that can act as physical support and in some times also as nutrient sources [13]. Generally, the enzymatic production in SSF has advantages over SbmF, as higher productivity 
fermentation, absence of contaminant organisms, concentrated product formation and use of agroindustrial residues as substrates [14].

Enzyme immobilization is undertaken either for the purpose of basic research or for use in technical processes of commercial interests $[15,16,17]$. Immobilized enzymes offer advantages over the use of conventional chemical catalysts as they exhibit higher catalytic activity, higher degree of specificity could be produced in large amounts and are economically viable [18]. The use of safety and low cost matrices allows the immobilization method to be achieved successfully in industrial food field without additional production cost. Immobilization by entrapment is based on the localization of an enzyme within the lattice of a polymer matrix or membrane. The feasibility of using synthetic sponge as a carrier for immobilization was reported by many authors [19]. The lattice structure of polyvinyl alcohol (PVA) sponge characterized by very dense porosity and specific pore volume are very high. These properties recommended PVA sponge strongly to be used for the enzyme entrapment [20].

In this study, the honey isolate Aspergillus niger EM77 was a good invertase producer in the presence of wheat bran as the sole nitrogen and carbon source. The parameters influencing the enzyme productivity such as incubation time, temperature, $\mathrm{pH}$, carbon and nitrogen sources, in addition to metals ions were studied. The enzyme was partially purified and successfully immobilized in (PVAsp Gs), the properties of the free and immobilized enzyme was studied. The results indicated to the novelty of Aspergillus niger EM77 (KF774181) invertase as thermo-philic and extreme-halophilic enzyme. This features recommended it strongly to be applied in industrial field.

\section{MATERIALS AND METHODS}

\subsection{Microorganism (Isolation \& Identification)}

The fungal honey isolate was previously isolated from Yamane honey bee collecting nectar from mountain flower. Honeys samples are fresh non treated ripe honey (directly collected in beehives). It was identified based on morphological characterization and 18S rRNA sequence analysis (data not published yet). It was designed as Aspergillus niger EM77 and Gene Bank database was achieved in BLASTN searches at the National Center for Biotechnology Information (NCBI) site (http://www.ncbi.nlm.nih.gov) and take an Accs. NO (KF774181).

\subsection{Inoculum Preparation}

Four-days-old slant was gently scratched with sterilized needle, then one $\mathrm{ml}$ of $A$. niger EM77 spore suspension was injected in Czapek's Dox medium (CDM) contained (g/L): 20.0 sucrose; $2.0 \mathrm{NaNO}_{3} ; 1.0$ $\mathrm{K}_{2} \mathrm{HPO}_{4} ; 0.5 \mathrm{MgSO}_{4} .7 \mathrm{H}_{2} \mathrm{O}$ and $0.5 \mathrm{KCl}$, the $\mathrm{pH}$ was adjusted to be 6.0. The culture was incubated in a rotary shaker at $150 \mathrm{rpm}$ for three days at $30^{\circ} \mathrm{C}$. The fungal growth was used for inculating the experimental flasks.

\subsection{Solid State Fermentation}

Five grams of wheat bran in $250 \mathrm{ml}$ Erlenmeyer flasks was thoroughly mixed with eight $\mathrm{ml}$ of the following medium (BM) (g/l): $2.0 \mathrm{NaNO}_{3} ; 1.0 \mathrm{~K}_{2} \mathrm{HPO}_{4}$; $0.5 \mathrm{MgSO}_{4} .7 \mathrm{H}_{2} \mathrm{O}$ and $0.5 \mathrm{KCl}$. at $\mathrm{pH} 6.0$. The flasks were autoclaved at $121^{\circ} \mathrm{C}$ for $30 \mathrm{~min}$. They were, cooled to room temperature and each flask was inoculated with $2 \mathrm{ml}\left(10^{6}\right.$ cells) (CDM). The flasks were incubated statically for three days at $30^{\circ} \mathrm{C}$.

\subsection{Enzyme Extraction}

One hundred $\mathrm{ml}$ of distilled water were added to each flask and the culture was shaked for 60 minutes on a rotary shaker at $150 \mathrm{rpm}$. Then, the suspension was filtered on whatman filter paper No 1 . The obtained filtrate was centrifuged and the supernatant was used to assay the invertase activity.

\subsection{Enzyme Assay}

The invertase activity was determined according to the method described by Miller (1959) [21] using $2 \%$ sucrose as substrate in sodium acetate buffer, $0.1 \mathrm{mM}$, $\mathrm{pH}$ 5.2. The reaction mixture was composed by $500 \mu \mathrm{l}$ of substrate and $500 \mu \mathrm{l}$ of enzymatic sample. The reaction: one $\mathrm{ml}$ of dinitrosalicylic acid reagent DNS was added to each tube and boiled for 5 minutes in boiling water bath. The obtained color was measured at $540 \mathrm{~nm}$ according to Miller (1959) [21]. One unit of enzyme activity $(U)$ was defined as amount of enzyme that releases $1 \mu \mathrm{mol}$ of glucose per min under the assay conditions. The values of enzymatic activity were expressed as $\mathrm{U} / \mathrm{g}$ of substrate for SSF.

\subsection{Effect of Different Temperatures}

Incubation was carried out at different temperatures $\left(25,30,35,40 \& 45^{\circ} \mathrm{C}\right)$ to study their effect on the invertase activity. Cultivation was carried out in BM medium. 


\subsection{Effect of Different pH Values}

The $\mathrm{pH}$ of culture medium was adjusted with diluted $\mathrm{HCl}$ or $\mathrm{NaOH}$ from 2 to $9 \mathrm{pH}$. Cultivation was carried out in BM medium at the optimum temperature obtained from the above treatment.

\subsection{Effect of Different Carbon Sources}

In order to measure the effect of different carbon sources on $A$. niger EM77 invertase activity, the sucrose in BM medium was replaced with $2 \%(\mathrm{w} / \mathrm{v})$ of different carbon sources (fructose, galactose, mannose, lactose, casein, glucose, cellulose and pectin). The cultivation was done at the optimum conditions.

\subsection{Effect of Different Nitrogen Sources}

Addition effects of equi-molar amounts from different inorganic nitrogen $\left(\mathrm{Na}_{2} \mathrm{NO}_{3}, \mathrm{NH}_{4} \mathrm{NO}_{3}\right.$, $\left(\mathrm{NH}_{4}\right)_{3} \mathrm{PO}_{4},\left(\mathrm{NH}_{4}\right)_{2} \mathrm{HPO}_{4}, \mathrm{NH}_{4} \mathrm{H}_{2} \mathrm{PO}_{4}, \mathrm{NH}_{3} \mathrm{Cl}$, and $\left.\mathrm{KNO}_{3}\right)$ and organic nitrogen (yeast extract or peptone) sources on enzyme production of fungal isolate were also studied. The cultivation was applied at the above optimum conditions.

\subsection{Fractional Precipitation with Ethanol}

Ethanol (30, 50, 70 and $90 \%)$ was added slowly to the ice-cold enzyme solution and left to precipitate for 30 minutes. After removing the precipitated fraction by centrifugation in a cooling centrifuge at $4000 \mathrm{rpm}$ for 10 min, further ethanol was added to the supernatant fluid and the process was repeated until the final concentration of ethanol was reached (90\%). Enzyme fractions obtained at 30, 50, 70 and $90 \%$ ethanol concentrations were dried over anhydrous calcium chloride, under reduced pressure at room temperature, weighed and used for invertase activity and protein estimation.

\subsection{Protein Determination}

This was determined by the method of [22] Bovine serum albumin was used as standard protein.

\subsection{Immobilization Technique}

Polyvinyl alcohol sponge (PVA sp) was washed several times by distilled water, squeezed to eject water and was cut into small pieces $(4 \mathrm{~mm} \times 4 \mathrm{~mm} \times 4$ $\mathrm{mm}$ ) using scissors. Then, each piece of synthetic sponge was inserted into the invertase fraction (40-
$80 \%$ ethanol enzyme fraction) (173 U/g carrier) dissolved in $2.0 \mathrm{ml}$ of $0.2 \mathrm{M}$ acetate buffer, $\mathrm{pH} 5.2$ at $4^{\circ} \mathrm{C}$ for $24 \mathrm{~h}$. For PVA sponge shielding agar starch (PVAsp Gs), the sponge pieces were immersed in $\left(18 \%\right.$ agar $+2 \%$ starch) liquefied solution at $45^{\circ} \mathrm{C}$, then it was removed, and the carrier was used after solidification.

\section{Immobilization Yield (U/g Carrier)}

It was calculated from the equation:

Immobilized enzyme (U/g carrier) = Immobilized enzyme activity (U/g carrier)/ Enzyme added (U/g carrier) - Unbound enzyme (U/g carrier) (\%) [23].

\section{Activity and Protein Determination}

The protein concentration of the immobilized enzyme was estimated by taking into consideration the protein concentration in the initial solution and of the unbound protein. The amount of protein immobilized on to and into the gel carrier $\mathrm{Pg}(\mathrm{mg} / \mathrm{g})$ was calculated using the following equation:

$$
P g=C_{o} V_{o}-C_{f} V_{f} / W
$$

Where $\mathrm{C}_{\mathrm{o}}$ is the initial protein concentration $(\mathrm{mg} / \mathrm{ml})$, $C_{f}$ the protein concentration of the filtrate $(\mathrm{mg} / \mathrm{mL}), V_{o}$ the initial volume of the enzyme solution $(\mathrm{ml}), V_{f}$ the volume of filtrate $(\mathrm{mL})$, and $\mathrm{w}$ is the weight of gel carrier used (g). For determination of activity of the immobilized enzyme, one piece carrier equivalent to $(0.3 \mathrm{~g})$ were incubated into $2 \mathrm{~mL}$ of $2 \%$ sucrose $(\mathrm{w} / \mathrm{v})$ for 15 min at $40^{\circ} \mathrm{C}$ and invertase activity was assayed as described above [24].

\subsection{Operation Stability}

It was performed with immobilized invertase on (PVAsp Gs) contained about $135 \mathrm{U}$ of the enzyme. The tested sample was incubated with $0.5 \mathrm{ml}$ buffered sucrose solution $(0.2 \mathrm{M}$ acetate buffer at $\mathrm{pH} 5.2)$ at $40^{\circ} \mathrm{C}$ for $20 \mathrm{~min}$. At the end of the reaction period, it was removed, washed with distilled water and resuspended in $0.5 \mathrm{ml}$ of freshly prepared substrate to start a new run. The supernatant was assayed for invertase activity.

\subsection{Optimization of the Immobilization Yield (\%)}

\subsubsection{Loading Time}

For optimum loaded time determination, the free enzyme (173 U) was loading in (PVAsp Gs) carrier and incubated at $4^{\circ} \mathrm{C}$ for different periods $(2,6,14,18,24$, 
36 , and 48 hours). After loading time was finished, the carrier was washed twice thoroughly for 30 min with 0.2 $\mathrm{M}$ acetate buffer at $\mathrm{pH} 5.2$ to get rid of any unbound enzyme and the usual assay has been implicated. Then, the invertase activity was determined for each time interval and expressed as immobilization yield (\%).

\subsubsection{Enzyme Loading Capacity}

Different enzyme protein concentrations (69.4, $104.7,138.8,173.5,208.8$ and $242.9 \mathrm{mg}$ ) incubated on (PVAsp Gs) at $4^{\circ} \mathrm{C}$ for $18 \mathrm{~h}$. Then the invertase activity was determined and expressed as immobilization yield $(\%)$.

Properties of free and immobilized invertase enzyme by $A$. niger EM77 (KF774181)

\subsubsection{Reaction Time}

The reaction mixture consisted of $0.5 \mathrm{ml}$ buffered sucrose solution $(0.2 \mathrm{M}$ acetate buffer at $\mathrm{pH} 5.2) 2 \%$ and $0.5 \mathrm{ml}$ of the enzyme solution (free enzyme) or one piece of immobilized enzyme. Enzyme reaction was conducted at $30^{\circ} \mathrm{C}$ at different time intervals $(5-30$ $\min )$.

\subsubsection{Effect of Different Temperatures}

Identical reaction mixtures were incubated at different temperatures $\left(30-80^{\circ} \mathrm{C}\right)$ for $15 \mathrm{~min}$ at $\mathrm{pH}$ 5.2. The enzyme assay was done as discussed previously.

\subsubsection{Thermal Stability}

The effect of temperature on enzyme stability was carried out by preheating the invertase enzyme at different temperatures $\left(40-85^{\circ} \mathrm{C}\right)$ for different time intervals $(15,30,40$ and $60 \mathrm{~min})$. At the end of the incubation time, the usual enzyme assay has been carried out at the preferable conditions for each of the partially purified and immobilized enzyme. Control was also carried out using the free and immobilized enzyme without preheating. Its activity was taken as $100 \%$.

\subsubsection{Effect of $\mathrm{pH}$ Value}

The effect of $\mathrm{pHs}$ on the enzyme activity was investigated in $0.1 \mathrm{M}$ citrate phosphate buffer $(\mathrm{pH} 5.0$ 7.0), $0.1 \mathrm{M}$ phosphate buffer $(\mathrm{pH} 7.0-8.0)$ and $0.1 \mathrm{M}$ Tris - HCL buffer ( $\mathrm{pH} 8.0-9.0)$, using the experimental assay conditions.

\section{RESULTS AND DISCUSSION}

Recent advances in industrial biotechnology process are exploited for an economic utilization of wastes for producing valuable products. Studies have been carried out by using synthetic medium for invertase preparation. A little attention has been paid on its production from un-conventional inexpensive sources $[25 ; 26 ; 27 ; 28]$. Within this context, the honey isolate Aspergillus niger EM77 (KF774181) showed good invertase productivity in the presence of wheat bran as a complete medium (114.0199 $\mathrm{U} / \mathrm{g}$ ) using solid state fermentation technique. In this finding, it was reported that filamentous fungus Aspergillus caespitosus is a good producer of intracellular and extracellular invertases under SSF condition and wheat bran as a substrate [29]. The optimum $\mathrm{pH}$, temperature and incubation period for enzyme productivity were $\mathrm{pH}$ $5.5,30^{\circ} \mathrm{C}$ and $72 \mathrm{~h}$ (data not shown). Similarly, $A$. flavus produced high levels of invertase under optimized culture conditions [30]. The maximum productivity was on 4th incubation day, $\mathrm{pH} 5.0$, and $30^{\circ} \mathrm{C}$ using fruit peel waste as a substrate. Also, it was reported that the optimum $\mathrm{pH}$, temperature and incubation period for Cladosporium Cladosporioides invertase production were $4,30^{\circ} \mathrm{C}$ and 4th day respectively [31]. The best carbon and nitrogen sources for invertase productivity were sucrose at $2 \%$ (144.39 $\mathrm{U} / \mathrm{g})$ and $\left(\mathrm{NH}_{4}\right)_{2} \mathrm{SO}_{4}$ at $0.15 \%(158.21 \mathrm{U} / \mathrm{g})$, respectively (Figures 1,2 ). The results were supported by the findings of [32] who reported that invertase production in some other fungi was induced by sucrose. It was reported in enhancement of $A$. flavus invertase production by addition of sucrose and yeast extract as nutritional factors [30]. The evaluating of different metal ions effect on Aspergillus niger EM77 (KF774181) showed that the highest productivity was achieved in the presence of $\mathrm{MnSO}_{4}(194.71 \mathrm{U} / \mathrm{g}$ ). Enzyme secretion was strongly inhibited by the presence of $\mathrm{Hg}^{2+}$ in the medium and to some extent by $\mathrm{Cu}^{2+}, \mathrm{Ca}^{2+}, \mathrm{Fe}^{2+}$ and $\mathrm{Mg}^{2+}, \mathrm{Pb}^{2+}$. Also, significant increase in the enzyme production was observed when $\mathrm{Mn}^{2+}$ was added in the medium (Figure 3). Alves et al., [33] reported that invertases from the Aspergillus nidulans and Emericela nidulans were activated by $\mathrm{Mn}^{2+}$. The enzyme was partially purified by $40-80 \%$ ethanol and achieved two fold purification (Table 1). In immobilization studies, the matrix characteristics and the mode of attachment of the enzyme to the matrix play an important role in determining the properties of the bound enzyme [6]. PVA sponge has a continuous pore structure featuring high porosity. This will cause the enzyme to leak out from the matrix. In this study, to overcome this problem the PVA sponge pieces was shielded with a thin agar starch layer (PVAsp Gs), the agar starch shielding method improved the 


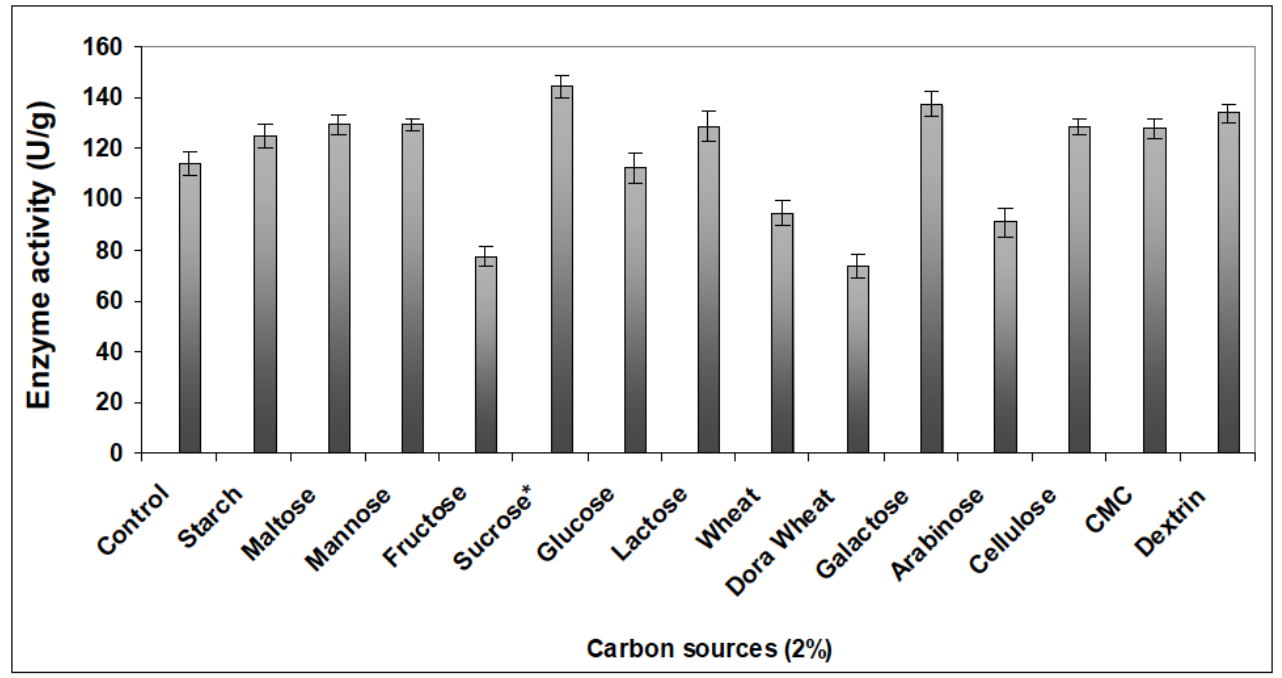

Figure 1: Effect of different carbon sources on A. niger EM77 (KF774181) invertase productivity.

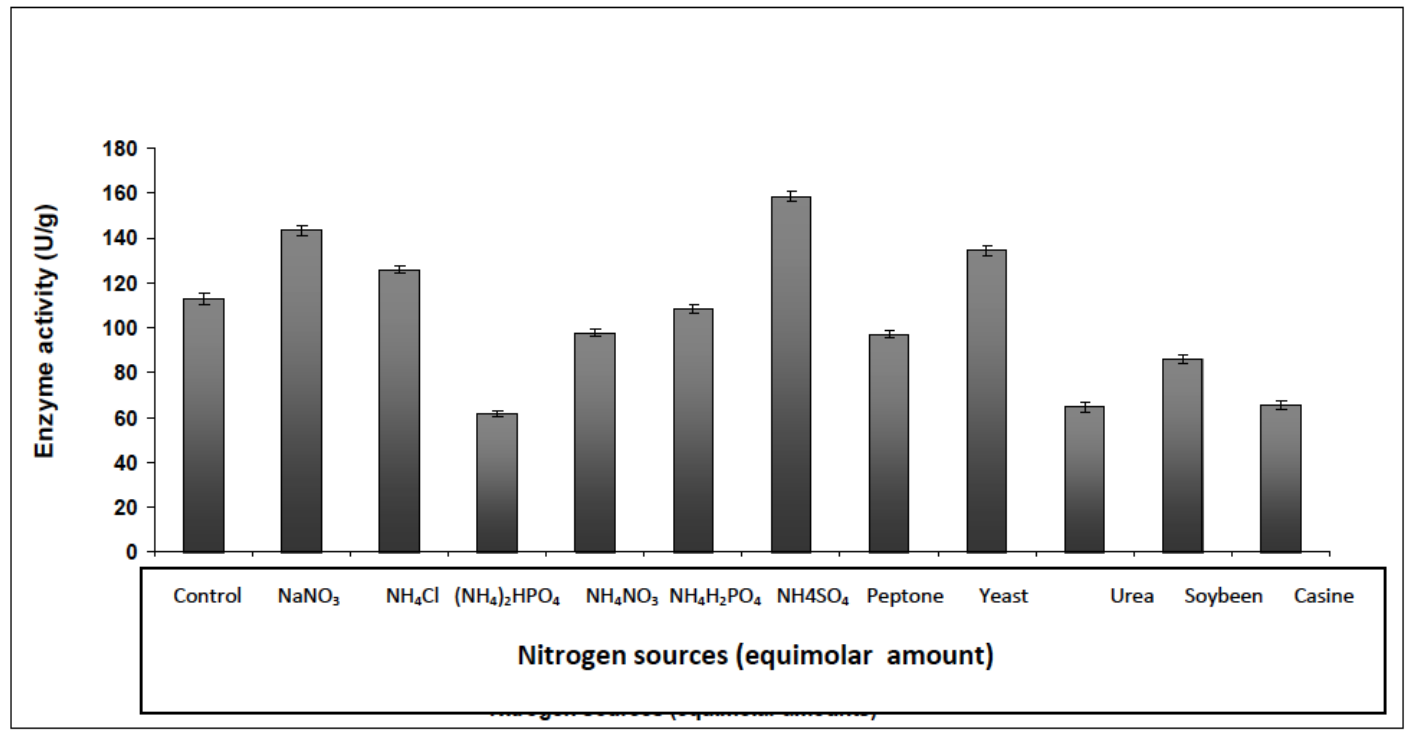

Figure 2: Effect of different nitrogen sources on A. niger EM77 (KF774181) invertase productivity.

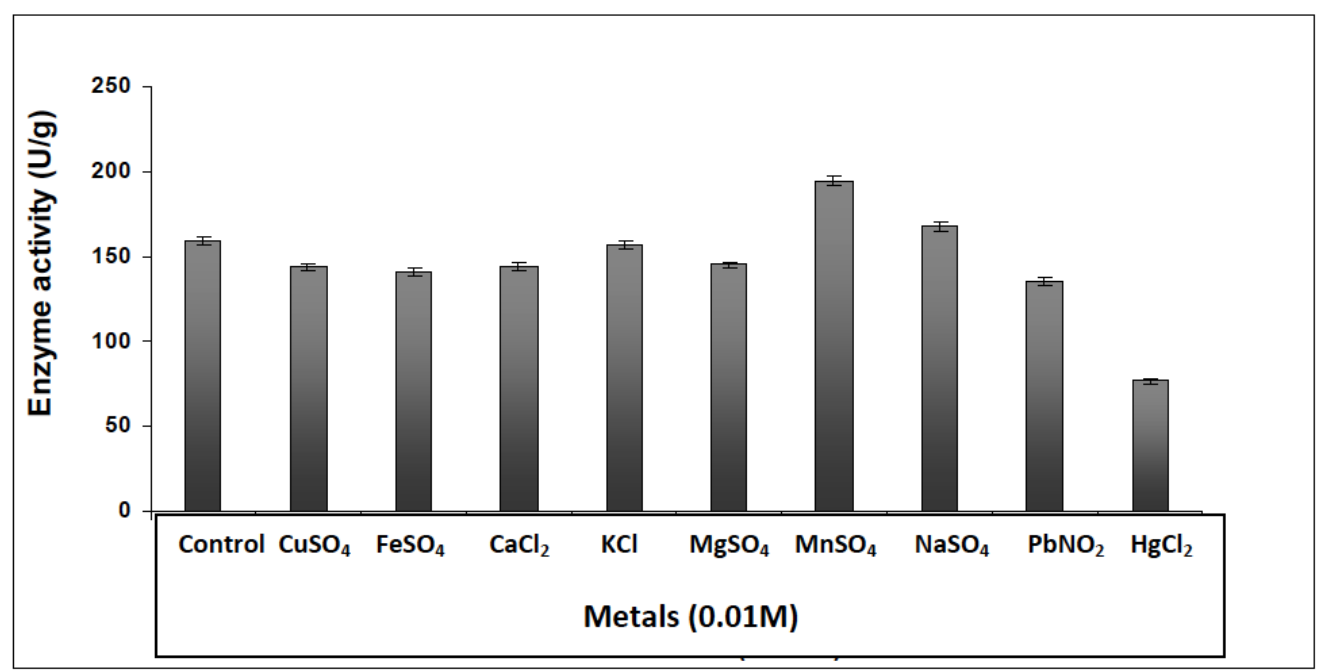

Figure 3: Effect of different metal ions on A. niger EM77 (KF774181) invertase productivity. 
Table 1: Partial Purification of Invertase Enzyme by Aspergillus niger EM77 (KF774180)

\begin{tabular}{|c|c|c|c|c|c|}
\hline $\begin{array}{c}\text { Immobilization } \\
\text { yield } \\
(\%)\end{array}$ & $\begin{array}{c}\text { Purification } \\
\text { fold }\end{array}$ & $\begin{array}{c}\text { Specific } \\
\text { activity } \\
\text { U/mg }\end{array}$ & $\begin{array}{c}\text { Total } \\
\text { protein } \\
\text { (mg) }\end{array}$ & $\begin{array}{c}\text { Total } \\
\text { unit } \\
(\mathbf{U})\end{array}$ & $\begin{array}{c}\text { Fraction precipitation } \\
\text { with }\end{array}$ \\
\hline \hline 100 & 1 & & & & Culture \\
filtrate
\end{tabular}

Table 2: Immobilization of Invertase Produced by Aspergillus niger EM77 (KF774181) on (PVA) Sponge by Two Methods

\begin{tabular}{|c|c|c|c|c|c|c|c|c|}
\hline Carriers & $\begin{array}{c}\text { Added } \\
\text { enzyme } \\
\text { (U) }\end{array}$ & $\begin{array}{l}\text { Protein of } \\
\text { added } \\
\text { Enzyme }\end{array}$ & $\begin{array}{c}\text { Bounded } \\
\text { enzyme } \\
\text { (U) }\end{array}$ & $\begin{array}{l}\text { Unbounded } \\
\text { enzyme } \\
\text { (U) }\end{array}$ & $\begin{array}{l}\text { Protein for } \\
\text { bounded } \\
\text { enzyme }\end{array}$ & $\begin{array}{c}\text { Protein for } \\
\text { unbounded } \\
\text { enzyme }\end{array}$ & \multicolumn{2}{|c|}{$\begin{array}{c}\text { Immobilization } \\
\text { yield (\%) } \\
\text { I/(A-B) } \%\end{array}$} \\
\hline PVAsp & 138.8 & 23.09 & 60.3 & 36.5 & 8.47 & 14.62 & 58.5 & \pm 1.83 \\
\hline PVAsp Gs & 138.8 & 23.09 & 70.4 & 38.5 & 5.33 & 17.75 & 70.18 & \pm 1.27 \\
\hline
\end{tabular}

immobilization yield from $58.9 \%$ in PVA sponge alone to $71 \%$ in (PVAsp Gs) (Table 2). The specific activity of the immobilized enzyme was $13.12 \mathrm{U} / \mathrm{ml}$ compared to 6.03 free form. This result considered as partial purification step and could be attributed to sponge high porosity. It was reported in the sponge structure which helped in entrapment most of the pectinase letting the undesired protein abroad [20]. Similar result was obtained by Esawy and Combet-Blanc [34]. The highest loading capacity $(71 \%)$ was reported at $18 \mathrm{~h}$ and remained constant till $48 \mathrm{~h}$ (Figure 4a). The enzyme loading at $29.5 \mathrm{mg}$ enzyme protein achieved the highest immobilization yield (75\%) (Figure $4 \mathbf{b}$ ). The optimum $\mathrm{pH}$ and temperature of the free and immobilized enzymes remained unchanged at $\mathrm{pH} 5.2$ and $50^{\circ} \mathrm{C}$ (Figure $5 \mathbf{a}, \mathbf{b}$ ). Similarly, it was reported that invertase immobilization in sawdust did not affect the optimum $\mathrm{pH}$ and temperature of the enzyme but it enhanced the $\mathrm{pH}$ and temperature stability [35]. As well as, It was reported that the immobilization did not affect the optimum $\mathrm{pH}$ but it increased the optimum temperature to $50^{\circ} \mathrm{C}$ compared to $45^{\circ} \mathrm{C}$ in case of the free enzyme [36]. Thermal stability was considered as a good enzyme criterion for industrial field. In this finding, thermal stability study was done at different temperatures (Figure $\mathbf{6 a}, \mathbf{b}$ ). The result indicated that

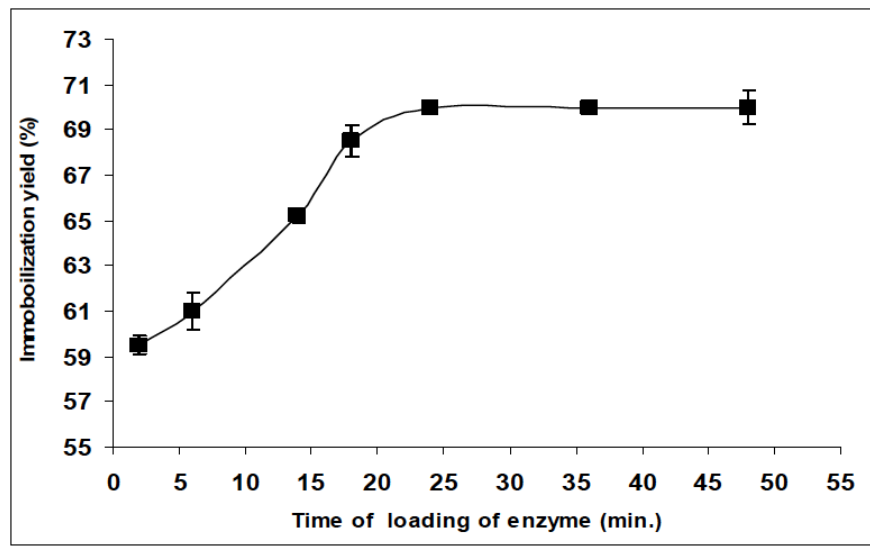

(a)

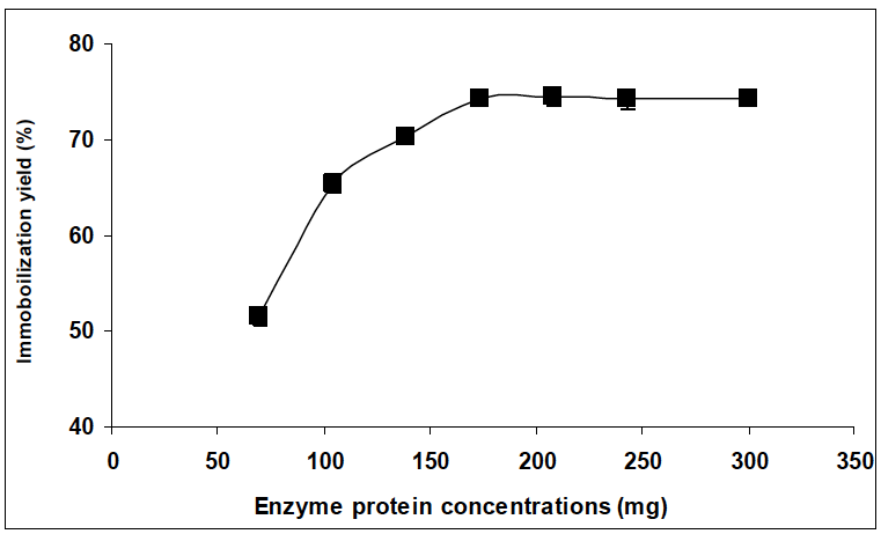

(b)

Figure 4: Evaluation of different loading time (a) and enzyme protein concentrations on enzyme loading the result expressed as immobilization yield (\%). 


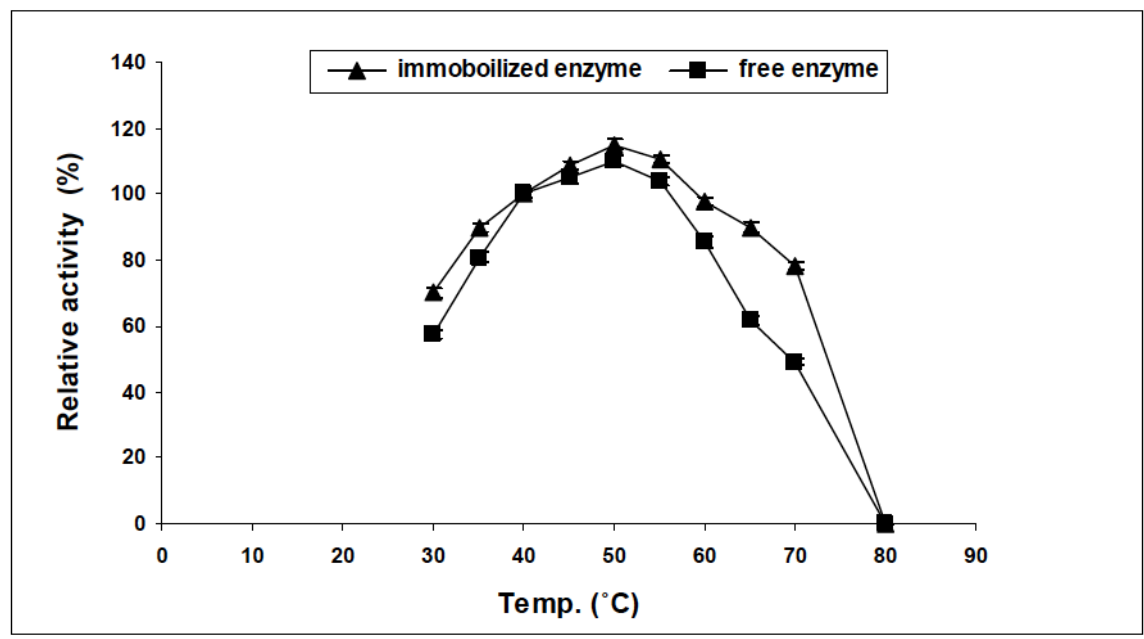

(a)

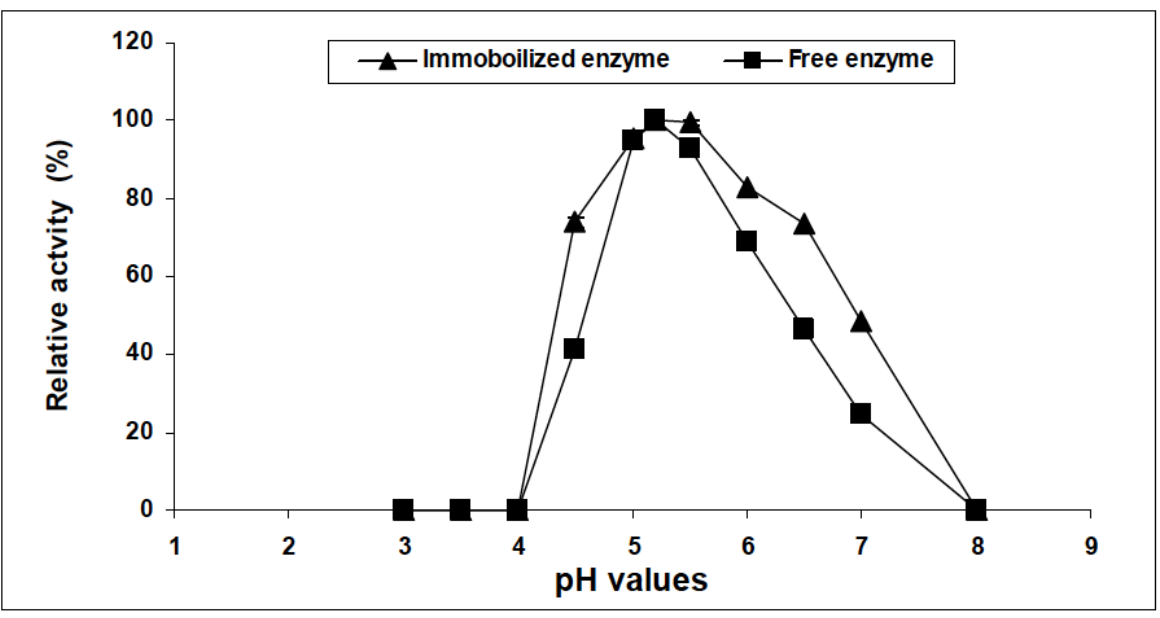

(b)

Figure 5: Effect of different temperatures (a) and pHs on the free and immobilized A. niger EM77 (KF774181) invertase.

the immobilization process improved the enzyme stability to great extent. Also, it showed that the free enzyme lost its activity completely at $70^{\circ} \mathrm{C}$ after 45 minute. On the other hand, the immobilized enzyme kept $80 \%$ of its original activity at the same conditions. On the other side, the immobilized form could keep $18 \%$ of its activity at $80^{\circ} \mathrm{C}$ after $15 \mathrm{~min}$. Similar results was obtained by [36].

Halophiles represent valuable sources of various biomolecules which can offer potential applications for biocatalysis and biotransformation [37]. Within this context, the halo-tolerant property was studied for the free and immobilized form. The result indicated that both the free and immobilized form characterized by extreme halophilic property, since the highest enzyme activity was obtained between 3.5-5 M and the enzyme activity work with good efficiency till $6 \mathrm{M}$ (Figure 7). Halophilic enzymes, have identical enzymatic features like their non-halophilic counterpart, but they exhibit different properties mainly in structure. Among these, two main points could be mentioned, (i) a high content of acidic amino-acids located predominantly at the protein surface and (ii) requirement for high salt concentration for better biological functions Enache and Kamekura [1]. It was reported in yeast invertase isolated form saline soil that the highest invertase activity was observed in the medium containing $1.7 \mathrm{mM}$ sodium chloride [38]. Mohmoud 2007 [35] reported that invertase kept $97 \%$ of its activity for a week even after washing with $6 \mathrm{M} \mathrm{NaCl}$. Enzyme reuses is very important criteria to evaluate the immobilization process efficiency. The results showed that the immobilized enzyme was reused 12 times with $29 \%$ activity loss (Figure 8). Awad et al., 2013 [24] reported that the reusability test proved the durability of the grafted alginate beads for 15 cycles with retention of $100 \%$ of the immobilized enzyme activity. All the previous properties recommended Aspergillus niger EM77 (KF774181) to be used in industrial field. 

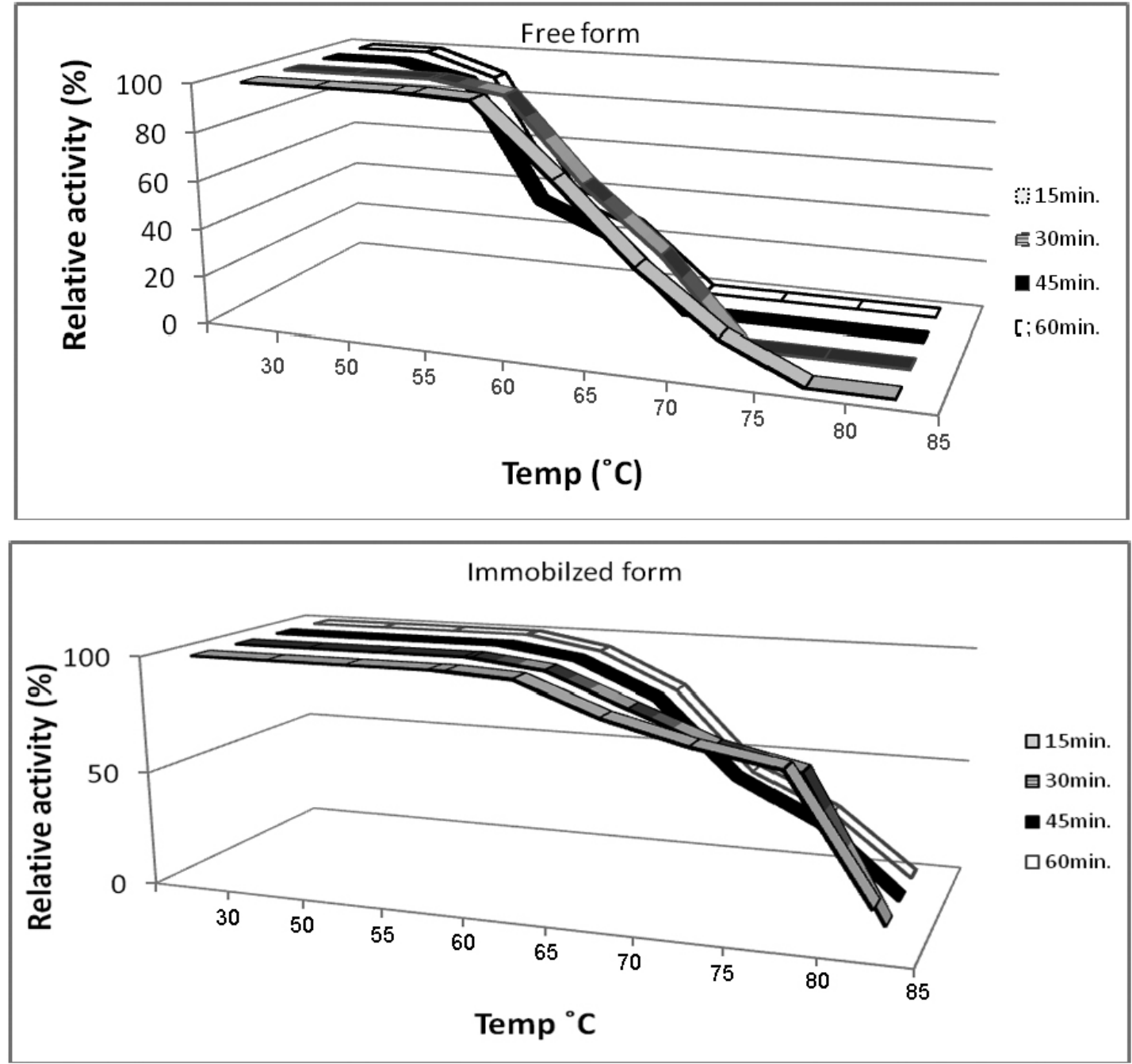

Figure 6: Thermal stability profile of free and immobilized A. niger EM77 (KF774181) invertase.

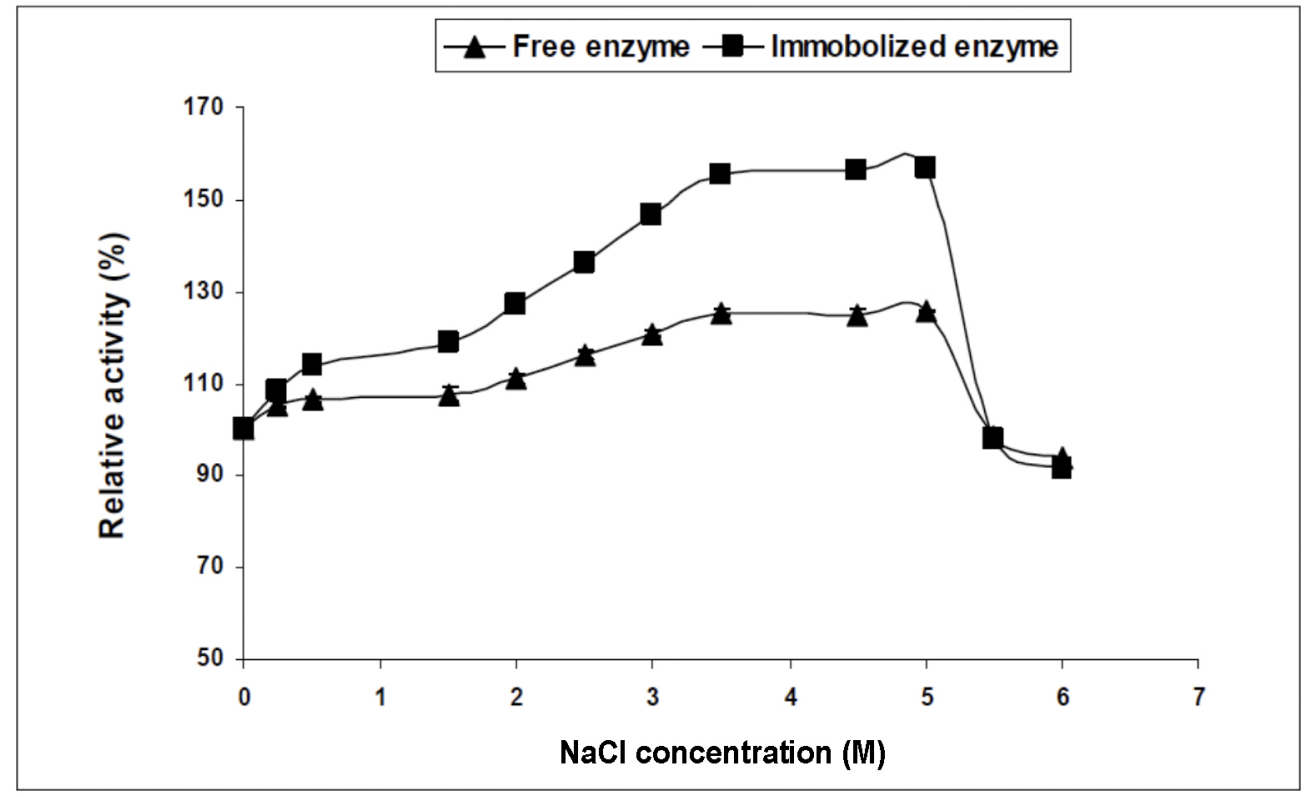

Figure 7: Effect of $\mathrm{NaCl}$ concentrations on free and immobilized A. niger EM77 (KF774181) invertase. 


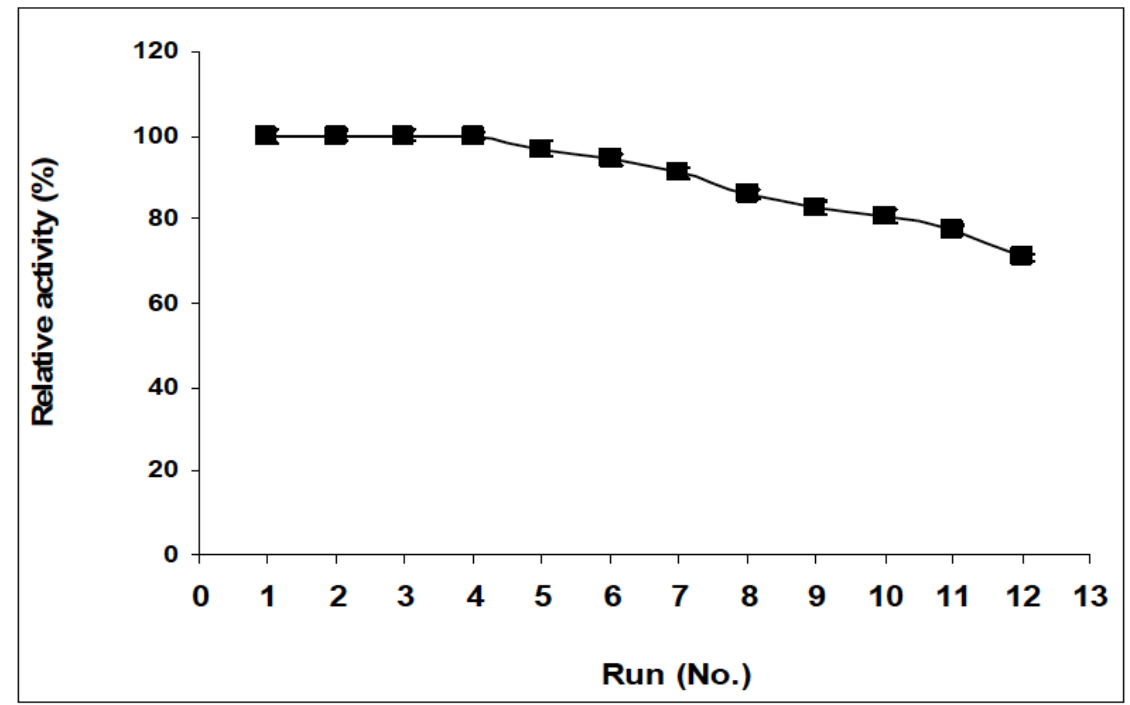

Figure 8: Reusability of enzyme immobilized.

\section{CONCLUSION}

Extreme environment is expected to have microorganisms have unique and valuable products. In this finding the honey isolate Aspergillus niger EM77 (NO.KF774181) was achieved a good invertase activity in the presence of waste material (wheat bran). Extensive investigations have been carried out aiming increasing the enzyme productivity including different incubation period, temp, $\mathrm{pHs}$, carbon and nitrogen sources in addition to metal ions. Also, a simple novel and low cost method was achieved to immobilize Aspergillus niger EM77 (NO.KF774181) invertase in (PVAsp Gs). The properties of the free and immobilized invertase pointed out to its novelty. This conclusion comes from the extreme halophilic feature of the free and immobilized enzyme, also its thermophilic character. These properties recommended it to be applied in industrial field.

\section{ACKNOWLEDGEMENTS}

This research was supported by the National Research Centre, Egypt. Thank you for my dear student Dr. Basem Salama for his sincere helping in fungal isolation.

\section{REFERENCES}

[1] Enache $M$, Kamekura $M$. The halophilic enzyme and their economical values. Rom J Biochem 2010; 47(1): 47-59.

[2] Esawy MA, Ahmed EF, Helmy WA, Mansour NM, ElSenousy WM, El-Safty MM. Production of levansucrase from novel honey Bacillus subtilis isolates capable of producing antiviral levans. Carbohydrate polymers. 2011; 36: 823-30. http://dx.doi.org/10.1016/j.carbpol.2011.05.035

[3] Esawy MA, Mansour SH, Ahmed EF, Hassanein NM, ElEnshasy HA. Characterization of Extracellular Dextranase from a Novel Halophilic Bacillus subtilis NRC-B233b a Mutagenic Honey Isolate under Solid State Fermentation. Journal of Chem 2012; 9: 1494-510. http://dx.doi.org/10.1155/2012/860619

[4] Madern D, Ebel C, Zaccai G. Halophilic adaptation of enzymes. Extremophiles. 2000; 4: 91-8. http://dx.doi.org/10.1007/s007920050142

[5] Marhuenda-Egea FC., Piera-Velazquez S., Cadenas C., Cadenas E. Reverse micelles in organic solvents: a medium for the biotechnological use of extreme halophilic enzymes at low salt concentration, Archaea 2002; 1: 105-11. http://dx.doi.org/10.1155/2002/626457

[6] Kotwal SM, Shankar V. Immobilized invertase. Biotechnol Adv 2009, 27(4), 311-22.

http://dx.doi.org/10.1016/j.biotechadv.2009.01.009

[7] Aleksanyan ER, Markosyan LS. Microbial $\beta$ fructofuranosidase (survey). Appl Biochem Microbiol 1986 22: $133-45$.

[8] Belcarz A, Ginalska G, Penel C. The novel non-glycosylated invertase from Candida utilis (the properties and the conditions of production and purification). J Biochem et Biophys Acta- Protein Structure and Mol Enzymol 2002; 1594: 40-53. http://dx.doi.org/10.1016/S0167-4838(01)00279-5

[9] Bhatti HN, Asgher M, Abbas A, Nawaz R, Sheiki MA. Studies on kinetics and thermostability of a novel acid invertase from Fusarium solani. J Agric Food Chem 2006; 54: 4617-23. http://dx.doi.org/10.1021/jf053194g

[10] Yoshikawa J, Amachi S, Shinoyama H, Fujii H. Multiple $\beta$ fructofuranosidases by Aureobasidium pullulans DSM 2404 and their roles in the fructooligosaccharide production. FEMS Microbiol Lett 2006; 265: 159-63. http://dx.doi.org/10.1111/j.1574-6968.2006.00488.x

[11] Aranda C, Robledo A, Loera O, Contreras-Esquivel JC Rodrigues R, Aguilar CN. Fungal invertase expression in solid-state fermentation. Food Technol Biotechnol 2006; 44(2): 229-33.

[12] Romero-Gómez S, Augur C, Viniegra-González G. Invertase production by Aspergillus niger in submerged and solid-state fermentation. Biotechnol Lett 2000; 22: 1255-8. http://dx.doi.org/10.1023/A:1005659217932

[13] Vandenberghe LPS, Soccol CR, Pandey A, Lebeault JM. Solid state fermentation for the synthesis of citric acid by Aspergillus niger. Bioresour Technol 2000; 74: 175-8. http://dx.doi.org/10.1016/S0960-8524(99)00107-8 
[14] Sangeetha PT, Ramesh MN, Prapulla SG. Recent trends in the microbial production, analysis and application of Fructooligosaccharides. Trends Food Sci Technol 2005; 16: 442-57.

http://dx.doi.org/10.1016/j.tifs.2005.05.003

[15] Cirpan A, Alkan S, Toppare L, Yagcı Y, Hepuzer Y. Conducting graft copolymers of poly (3-methylthienyl methacrylate) with pyrrole and thiophene. J Polym Sci Part A Polym Chem 2002; 40: 4131-40.

http://dx.doi.org/10.1002/pola.10511

[16] Danisman T, Tan S, Kacar Y, Ergene A. Covalent immobilization of invertase on microporous pHEMA-GMA membrane. Food Chem 2004; 85: 461-6.

http://dx.doi.org/10.1016/j.foodchem.2003.07.015

[17] Erginer R, Toppare L, Alkan S, Bakir U. Immobilization of invertase in functionalized copolymer matrices. Reactive and Funct Polym 2000; 45: 227-33. http://dx.doi.org/10.1016/S1381-5148(00)00036-5

[18] Ahmad S, Anwar A, Saleemuddin M. Immobilization and stabilization of invertase on cajanus cajan lectin support. Bioresour Technol 2001; 79: 121-7.

http://dx.doi.org/10.1016/S0960-8524(01)00053-0

[19] Hanaki S, Hirunmasuwan K, Matsuo T. Protection of methanogenic bacteria from low $\mathrm{pH}$ and toxic materials by immobilization using polyvinyl alcohol. Water Res 1994; 28: 877-85.

http://dx.doi.org/10.1016/0043-1354(94)90094-9

[20] Esawy MA, Gamal AA, Kamelb Z, Ismail AMS, F. AbdelFattah A. Evaluation of free and immobilized Aspergillus niger NRC1ami pectinase applicable in industrial processes. Carbohyd Polym 2013; 92: 1463-9. http://dx.doi.org/10.1016/j.carbpol.2012.10.061

[21] Miller GL. Use of dinitrosalicylic acid reagent for determination of reducing sugar. Anal Chem 1959; 31(3): 426-8.

http://dx.doi.org/10.1021/ac60147a030

[22] Lowry $\mathrm{OH}$, Rosebrough NJ, Farr AL, Randall RJ. Protein measurement with folin phenol reagent. J Biol Chem 1951; 193: 265-75.

[23] Abdel Naby AM, Hshem MA, Esawy MA. Immobilization of Bacillus subtilis $\alpha$-amylase.and characterization of its enzyme properties. Microb Res 1998; 153: 319-25. http://dx.doi.org/10.1016/S0944-5013(99)80044-5

[24] Awad GEA, Amera H, El-Gammal EW, Helmy WA, Esawy MA, Elnashar MMM. Production optimization of invertase by Lactobacillus brevis $\mathrm{Mm}-6$ and its immobilization on alginate beads. Carbohydr Polym 2013; 93: 740-6. http://dx.doi.org/10.1016/j.carbpol.2012.12.039

[25] Ashokkumar B, Kayalvizhi N, Gunasekaran P. Optimization of media for $\beta$-fructofuranosidase production by Aspergillus niger in submerged and solid state fermentation. Process Biochem 2001; 37: 331-8. http://dx.doi.org/10.1016/S0032-9592(01)00204-7

[26] Rashad MM, Mahmoud AEE, Desouky MA, Nooman MU. Purification and characterization of extra and intracellular $\beta$ fructofuranosidase from Saccharomyces cerevisiae growing on Eichhornia crassipes leaf extract. Deut Lebensmittel Rundschau 2006; 102 :157-166.
[27] Guimaraes LHS, Terenzi HF, Polizeli MLT, Jorge JA. Production and characterization of a thermostable extracellular $\beta$-d-fructofuranosidase produced by Aspergillus ochraceus with agroindustrial residues as carbon sources. Enzyme Microb Technol 2007; 42: 52-7. http://dx.doi.org/10.1016/j.enzmictec.2007.07.021

[28] Guimaraes LHS, Somera AF, Terenzi HF, Polizeli MLTM, Jorge JA. Production of $\beta$-fructofuranosidases by Aspergillus niveus using agroindustrial residues as carbon sources: Characterization of an intracellular enzyme accumulated in the presence of glucose. Process Biochem 2009; 44: 237-41. http://dx.doi.org/10.1016/j.procbio.2008.10.011

[29] Alegre ACP, Polizeli M LTM, Terenzi HF, Jorge JA, Guimaraes L.H.S. Production of thermostable invertases by Aspergillus caespitosus under submerged or solid state fermentation using agroindustrial residues as carbon source. Braz J Microbiol 2009; 40: 612-22. http://dx.doi.org/10.1590/S1517-83822009000300025

[30] Uma C, Gomathi D, Muthulakshmi C, Gopalakrishnan VK. Production, purification and characterization of invertase by Aspergillus flavus using fruit peel waste as substrate. Adv Biol Res 2010; 4(1): 31-6.

[31] Uma C, Gomathi D, Ravikumar G, Kalaiselvi M, Palaniswamy M. Production and properties of invertase from a Cladosporium cladosporioides in SmF using pomegranate peel waste as substrate. Asian Pac J Trop Biomed 2012; 144: 605-11.

http://dx.doi.org/10.1016/S2221-1691(12)60282-2

[32] Cairns AJ, Howarth CJ, Pollock CJ. Characterization of acid invertase from the snow mould Monographella nivalis: A mesophilic enzyme from a psychrophilic fungus. J New Physiologist 1995; 130: 391-400. http://dx.doi.org/10.1111/j.1469-8137.1995.tb01833.x

[33] Alvesa AS, AdãobDH, Ferreroc TJ, Marquesa JC, Costad MJ, Patrício J. Benthic meiofauna as indicator of ecological changes in estuarine ecosystems: The use of nematodes in ecological quality assessment. Ecol Indic 2013; 24: 462-75. http://dx.doi.org/10.1016/j.ecolind.2012.07.013

[34] Esawy MA, Combet-Blanc Y. Immobilization of Bacillus licheniformis 5A1 milk-clotting enzyme and characterization of its enzyme properties. World J Microbiol Biotechnol 2006; 22: $197-200$. http://dx.doi.org/10.1007/s11274-005-9018-z

[35] Mahmoud DAR. Immobilisation of invertase by a new economical method using wood sawdust waste. Aust J Basic Appl Sci 2007; 1: 364-72.

[36] Tümtürk H, Tufan Y. Immobilization of invertase onto dimer acid-co-alkyl polyamine. J Appl Polym Sci 2004; 93(4): 152630. http://dx.doi.org/10.1002/app.20623

[37] Schiraldi C, Rosa MD. The production of biocatalysts and biomolecules from extremophiles. Trends Biotechnol 2002; 20: $515-21$

http://dx.doi.org/10.1016/S0167-7799(02)02073-5

[38] Sarehs A, Alirezaei AA. Evaluation of invertase activity in yeast isolated from saline soil. J Microbiol World 2010; 3(1): 31-9.

\section{DOI: http://dx.doi.org/10.6000/1927-3037.2014.03.02.1}

(C) 2014 Esawy et al.; Licensee Lifescience Global.

This is an open access article licensed under the terms of the Creative Commons Attribution Non-Commercial License (http://creativecommons.org/licenses/by-nc/3.0/) which permits unrestricted, non-commercial use, distribution and reproduction in any medium, provided the work is properly cited. 